\title{
Periradicular Repair after Two-Visit Endodontic Treatment Using Two Different Intracanal Medications Compared to Single-Visit Endodontic Treatment
}

\author{
Adriana M. Vieira SILVEIRA ${ }^{1}$ \\ Hélio P. LOPES ${ }^{2}$ \\ José F. SIQUEIRA Jr ${ }^{2}$ \\ Sérgio B. MACEDO 3 \\ Alberto CONSOLARO ${ }^{4}$ \\ ${ }^{1}$ Department of Endodontics, School of Dentistry, José do Rosário Vellano University, Alfenas, MG, Brazil; \\ University Center Newton Paiva, Belo Horizonte, MG, Brazil \\ ${ }^{2}$ Department of Endodontics, School of Dentistry, Estácio de Sá University, Rio de Janeiro, RJ, Brazil \\ ${ }^{3}$ Department of Oral and Maxillofacial Surgery, School of Dentistry, Catholic University of Brasilia, Brasilia, DF, Brazil \\ ${ }^{4}$ Department of Stomatology (Pathology), School of Dentistry of Bauru, University of São Paulo, Bauru, SP, Brazil
}

\begin{abstract}
The number of appointments necessary to treat infected root canals is one of the most controversial issues in endodontics. This study evaluated, in dogs, the response of the periradicular tissues to the endodontic treatment of infected root canals performed in a single visit or in two visits, using different interappointment dressings. Periradicular lesions were induced by inoculating Enterococcus faecalis in the root canals. After confirming that a periradicular lesion developed, the root canals were treated within one or two visits, using either ozonized oil or calcium hydroxide in camphorated paramonochlorophenol (CMCP) as an intracanal medication. After 6 months, the animals were sacrificed and the specimens were processed for histological and histobacteriological analysis. The root canals treated in a single visit showed a success rate of $46 \%$. When a calcium hydroxide/CMCP-based interappointment intracanal medication was used, $74 \%$ of the cases were categorized as success. In cases where ozonized oil was used as the intracanal medication, a success rate of $77 \%$ was observed. These results of the present study demonstrated that the two-visit treatment offered a higher success rate compared to one-visit therapy. In addition, ozonized oil may potentially be used as an intracanal medication.
\end{abstract}

Key Words: endodontic infection, intracanal medication, endodontic treatment.

\section{INTRODUCTION}

Controversy has arisen as to the number of visits indicated for root canal therapy (1). One-visit endodontic treatment offers some potential advantages to both clinician and patient. In addition to being faster and very well accepted by patients, it may prevent the risks of root canal system contamination or recontamination between the clinical appointments. In cases of vital pulp, there seem to be a consensus regarding the fact that as treatment should ideally be completed in one session provided some factors, such as time, operator's skills and anatomical conditions, are favorable. Nevertheless, treatment in one session of necrotic pulps associated with periradicular lesions remains one of the most controversial issues in endodontics (2).

The outcome of endodontic treatment is unarguably the main factor to be taken into account to elect the number of therapeutical sessions. The success rate of the therapy is significantly increased when the endodontic infection is effectively eradicated before root canal filling (3-5). It has been shown that predict- 
able disinfection of the root canal system is only achieved with the placement of antimicrobial interappointment intracanal dressings $(6,7)$. Several medicaments have been recommended for use as intracanal dressings. Calcium hydroxide is the most widely used substance for this purpose, but its effectiveness may rely on the type of vehicle used (8).

The antimicrobial effects of ozone have long been recognized. The ozone gas was discovered by Schonbein in 1840 and comprises an alotropic variation of oxygen (9). Because it is highly unstable, the ozone gas must be incorporated to fluids, such as vegetal oils (olive or sunflower oil) (10). Ozone possesses strong antimicrobial activity, debriding effects, and can stimulate angiogenesis (9). It was used in a vapor-phase test as early as 1942 in an effort to reduce airborne bacterial infections (11). Ozone has been used for years as a disinfectant in France and has been suggested to be a good available alternative to present chlorination practice for treatment of domestic water (12). A study (13) revealed that ozone, at relatively low concentrations, effectively killed $E s$ cherichia coli cells as well as vegetative cells and spores of Bacillus cereus and Bacillus megaterium. More recently, Siqueira et al. (14) evaluated the antibacterial activity of the ozonized oil and calcium hydroxide pastes against bacterial species commonly associated with the etiology of periradicular diseases. Of the tested medicaments, ozonized oil was the most effective against the evaluated bacterial species.

The purpose of the present investigation was to evaluate histologically and histobacteriologically the response of periradicular tissues to the endodontic treatment of infected root canals performed in a single visit or in two visits using either ozonized oil or calcium hydroxide in camphorated paramonochlorophenol (CMCP) as an intracanal medication.

\section{MATERIAL AND METHODS}

Sixty-seven vital roots of mandibular premolars of six adult male mongrel dogs with a mean weight of $10 \mathrm{~kg}$ were used in this experiment. The dogs were anesthetized throughout all experimental procedures. They were initially sedated with intramuscular administration of $2.0 \mathrm{~mL}$ of dihydroxylazine chloridrate (Rompum; Bayer do Brasil S/A - Produtos Veterinários, São Paulo, SP, Brazil), 3.0 $\mathrm{mg} / \mathrm{kg}$ of body weight. Further, induction was achieved by intravenous administration of $230 \mathrm{mg} / \mathrm{kg}$ of body weight of sodium nembutal (Abbott Laboratórios do Brasil Ltda, São Paulo, SP, Brazil). The animals were maintained under intravenous administration of saline throughout the procedures.

Root canal infection was induced as follows. After completion of the access cavities, the pulps were removed using Hedstrom files and the canals were then copiously irrigated with sterile saline. Afterwards, the root canals were inoculated with $10 \mu \mathrm{L}$ of a 24 -h-culture of Enterococcus faecalis (ATCC 29212), containing approximately $1.5 \times 10^{8}$ colony-forming units. The root canals were coronally sealed with light-cured composite.

Ninety days later, periradicular lesions were radiographically confirmed in the inoculated teeth. Each tooth was cleaned with pumice, isolated with a rubber dam, and the tooth crown and the surrounding field were then cleaned with $3 \%$ hydrogen peroxide and decontaminated with iodine tincture. After removal of the coronal restoration, the root canals were sampled in order to check for successful colonization by E. faecalis. Sterile paper points were used to soak up the fluid in the canal and then transferred to tubes containing fresh thyoglycolate broth (Merck, KGaA, Darmstadt, Germany). After incubation at $37^{\circ} \mathrm{C}$ for $24 \mathrm{~h}$, an aliquot of $0.1 \mathrm{~mL}$ was streaked onto the surface of plates containing blood agar or Mitis salivarius agar. Plates were then incubated at $37^{\circ} \mathrm{C}$ for 48 $\mathrm{h}$. The colony forming units were harvest and examined using Gram-staining and E. faecalis identification was confirmed for representative colonies using speciesspecific polymerase chain reaction according to Siqueira and Rôças (15).

The working length was established using an electronic apex locator (Apex Finder A.F.A., Model 7005/Analytic Technology, Orange, CA, USA), and the root canals were then chemomechanically prepared using the alternated rotary motions technique, as described by Siqueira et al. (7). Apical preparation was done by instrumentation up to a \#40 K-file. Throughout instrumentation, the root canals were abundantly irrigated with $2.5 \% \mathrm{NaOCl}$ solution, $3 \mathrm{~mL}$ after each file size. After preparation, the canals were flooded with $17 \%$ EDTA solution, which was left in the canal for 3 minutes. A final irrigation with $5 \mathrm{~mL}$ of $2.5 \% \mathrm{NaOCl}$ solution was done and the canals were then dried with paper points.

Instrumented teeth were randomly assigned to experimental and control groups as follows: Group 1: root canals were filled in the same appointment with guttapercha and Sealer 26 sealer (Dentsply Ind. e Com. Ltda., 
Petrópolis, RJ, Brazil) by the lateral compaction technique $(\mathrm{n}=15)$; Group 2: root canals were dressed with calcium hydroxide/CMCP/glycerin. Glycerin and CMCP were used in a 1:1 ratio, vol:vol. Paste was prepared in a creamy consistency and was taken to the canals using Lentulo spirals. The teeth were temporized with light-cured composite and after 7 days the canals were filled as in group 1 $(\mathrm{n}=15)$. Group 3: canals were dressed with ozonized oil ( $99 \% \mathrm{O}_{3}, 1 \%$ fomblin, Cosmoproject, Parma, Italy), temporized with light-cured composite for 7 days and then filled in a second appointment as in group $1(\mathrm{n}=15)$. Ozonized oil was taken to the canals using insulin syringes.

Positive control group 1 consisted of root canals left empty without being filled $(n=6)$. Positive control group 2 consisted of teeth with induced periradicular lesions but without instrumentation $(\mathrm{n}=10)$. The negative control comprised 6 teeth with vital pulps, which were treated in a single-visit.

In all groups, after the last intracanal procedures, the teeth were coronally restored with light-cured composite. Six months after treatment, radiographs were taken before the animals were killed by an anesthetic overdose. The left and right common carotid arteries were exposed and perfused with $10 \%$ neutral-buffered formaldehyde. Jaws were then resected, fixed in formaldehyde solution and decalcified under agitation in 5\% buffered EDTA ( $\mathrm{pH}$ 7.0), which was renewed every 2 days. Individual blocks containing the experimental roots and surrounding periradicular tissues were embedded in paraffin, and serially sectioned to an average thickness of $6 \mu \mathrm{m}$. Alternate sections were stained with either hematoxylin and eosin or Brown and Brenn technique. Sections were examined with a light microscope. Examiners were blinded to the treatment groups.

Evaluation was based on a scale described by Katebzadeh et al. (16), as follows: $0=$ no inflammation and normal width of the periodontal ligament (PDL) space; $1=$ mild inflammation and/or widened PDL space; $2=$ moderated inflammation and detectable loss of apical bone; and $3=$ severe inflammation and severe destruction of apical and cortical bone. Specimens that received scores 0 or 1 after evaluation were considered as success while those that were attributed scores 2 or 3 were considered as failure.

\section{RESULTS}

The species E. faecalis was recovered from all root canals at the time of chemomechanical preparation, confirming successful colonization of the root canals. However, two cases showed a mixed infection, indicating that percolation of saliva must have occurred during the period of induction of periradicular lesions. Even so, all infected teeth were used in the analysis. However, four teeth (two from group 1 and two from group 3) were lost during histological processing.

The root canals treated in a single-visit showed a success rate of $46 \%$ (6 of 13 cases). In failed cases, which comprised most specimens in this group, periradicular tissues were intensely inflamed and areas of active root resorption were seen in some specimens (Fig. 1). Histobacteriological analysis revealed that most cases of this group still harbored bacteria on the root canal walls and sometimes within dentinal tubules. Bacterial cells were also seen at or near the apical foramens. When an intracanal medication with calcium hydroxide/CMCP/glycerin was used between
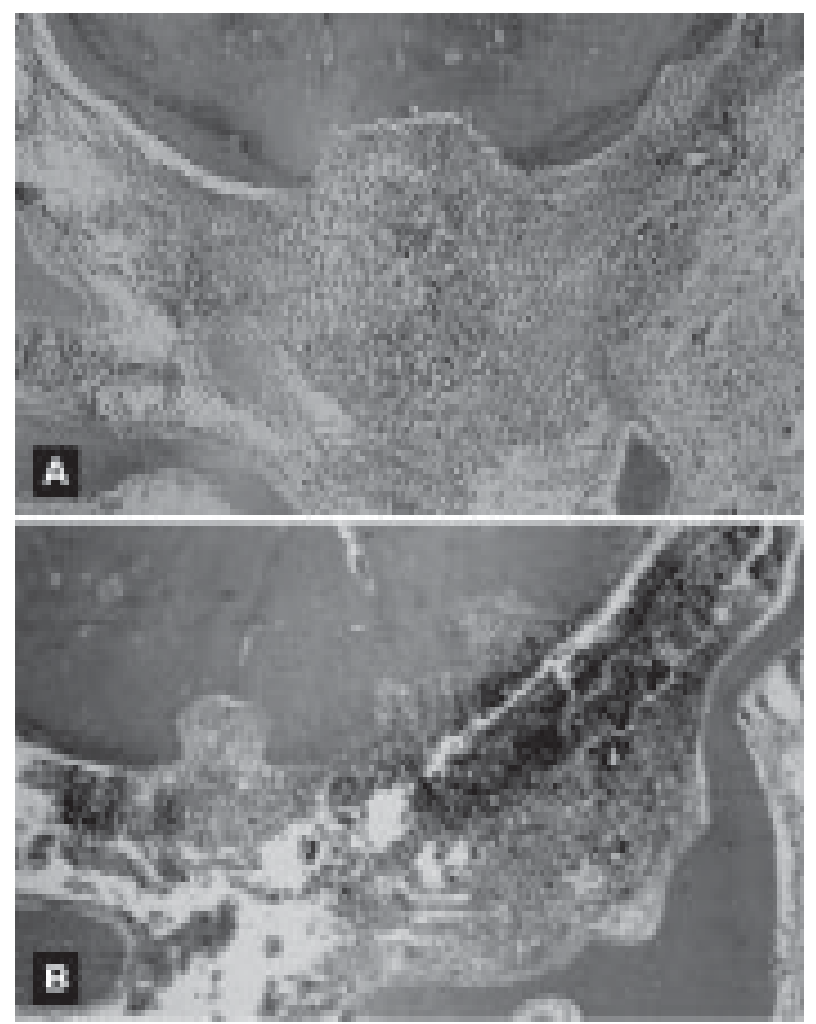

Figure 1. Specimens of the experimental group treated in one visit (A and B). Severe periradicular inflammation is seen and there is active root resorption in both specimens. These teeth received score 3 (failure) (original magnification $\times 100$ ). 
appointments, 11 of 15 cases $(74 \%)$ were categorized as success (Fig. 2). In cases where ozonized oil was used as an intracanal medication, a success rate of $77 \%$ (10 of 13) of the cases was observed (Fig. 3). Regardless of the interappointment medicament, most cases treated in two visits showed periradicular tissues free of inflammation or with mild inflammation, with evidence of healing. Areas of root resorption were usually covered by cementum, indicating that these areas were repaired and resorption ceased. The great majority of the root canals were bacteria-free, except for a few failed cases, in which bacteria were seen within multiple apical deltas. Results are summarized in Table 1.

All cases of vital pulps that were endodontically treated in one visit (negative control group) received score 0 (absence of periradicular inflammation), except

Table 1. Frequency of scores attributed to the histopathological sections of the experimental groups (\%).

\begin{tabular}{lcccc}
\hline \multirow{2}{*}{ Groups } & \multicolumn{4}{c}{ Scores } \\
\cline { 2 - 5 } & 0 & 1 & 2 & 3 \\
\hline Single-visit & $31 \%$ & $15 \%$ & $15 \%$ & $39 \%$ \\
CH/CMCP/gly & $27 \%$ & $47 \%$ & $20 \%$ & $7 \%$ \\
Ozonized oil & $46 \%$ & $31 \%$ & $8 \%$ & $15 \%$ \\
\hline
\end{tabular}

$\mathrm{CH}=$ calcium hydroxide; $\mathrm{CMCP}=$ camphorated paramonochlorophenol.

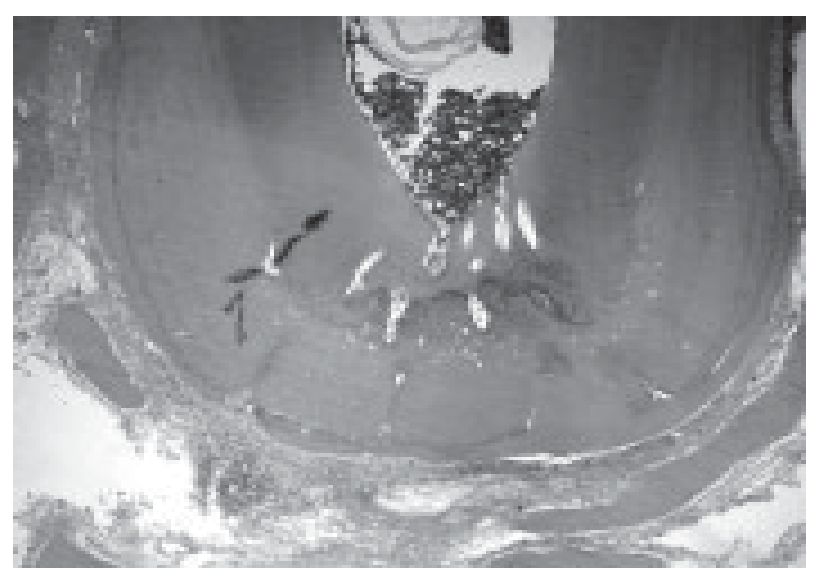

Figure 2. Two-visit treatment with $\mathrm{Ca}(\mathrm{OH})_{2} /$ camphorated paramonochlorophenol/glycerinasintracanalmedication. This specimen was categorized as score 0 (success) (original magnification $\times 100$ ). for one case that was scored 2. In this specimen, different bacterial forms were seen onto the root canal walls, suggesting contamination during intracanal procedures. All teeth of both positive controls were scored 3, except for one case of the positive control group 1 that received score 2 .

\section{DISCUSSION}

The results of the present investigation on periradicular tissue repair after endodontic treatment performed in one or two visits demonstrated that the use of an intracanal medication, such as a calcium hydroxide paste or a new medicament, ozonized oil, can offer a better outcome for endodontic therapy. These findings corroborate those from other studies $(3,4,16)$, which showed a higher success rate when infected root canals were treated in multiple visits compared to one visit.

The findings of the present study also suggest that ozonized oil has the potential to be used as an intracanal medicament. A previous study revealed that ozonized oil has strong antibacterial activity against several putative endodontic pathogens (14). In fact, ozone had its first important use in the disinfection of water. Ozone owes its excellent bactericidal, virucidal, and sporicidal activities to its powerful oxidizing properties $(9,14)$. Hydrolysis of ozonized oil can generate hydrogen peroxide, aldehydes, and cetones (17).

Hydrogen peroxide acts as an oxidant, which attacks essential cellular components, such as lipids,

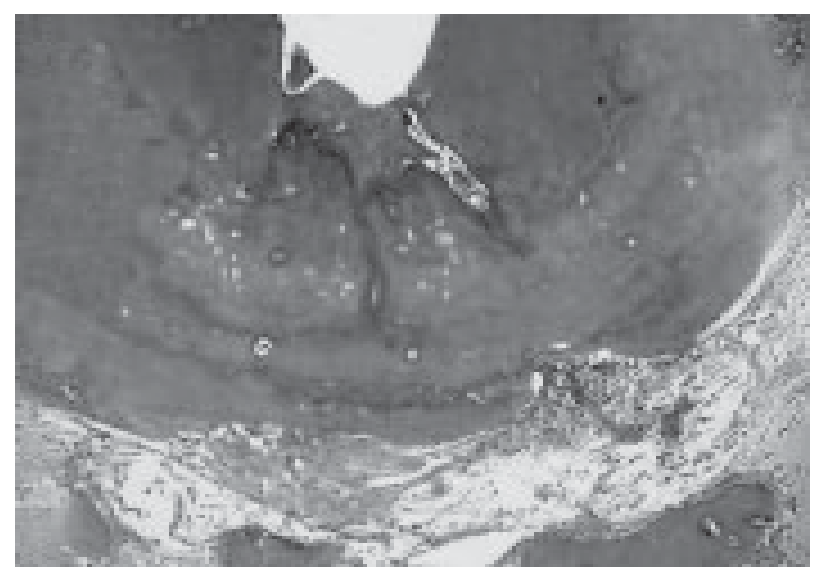

Figure 3. Two-visit treatment with ozonized oil as intracanal medication. This specimen was categorized as score 1 (success) (original magnification $\times 100$ ). 
proteins, and nucleic acids. As a consequence, it can induce disruption of the integrity of the bacterial cytoplasmic membrane, oxidation of enzymes and damage to DNA. Aldehydes have strong antibacterial activity, by inducing the formation of cross-bonds in proteins with subsequent inhibition of several enzymes involved in the bacterial metabolism. Aldehydes have also an alkylating effect on carboxyl, sulfhydryl and hydroxyl groups, present in nucleic acids and/or proteins. Unsaturated fatty acids in the oil may also have antimicrobial effects, which can be due to their incorporation in the cytoplasmic membrane, inducing lethal structural perturbations, disruption of the membrane integrity, and release of intracellular constituents (18). Therefore, the antimicrobial activity of the ozonized oil may be resultant from the action of aldehydes, unsaturated fatty acids, and hydrogen peroxide. Indeed, the oxidant effects of hydrogen peroxide may help explain the excellent antibacterial effects of ozonized oil on anaerobic bacterial species commonly found in endodontic infections (14).

Microorganisms can survive the effects of chemomechanical preparation in approximately $40-70 \%$ of the cases $(1,6,7)$. It is claimed that most of the surviving microorganisms die due either to the antimicrobial action of root canal filling material or to the absence of available nutrients in a filled root canal. Nonetheless, the results of this and other studies $(15,19)$ demonstrated that, in many cases, remaining microorganisms can survive in a filled root canal and be responsible for the persistence of a periradicular lesion.

In the present study, E. faecalis was inoculated in the root canals for periradicular lesion induction. This bacterial species is a Gram-positive facultative coccus that has been frequently found in association with failed root canal treatments, sometimes in single infections $(15,19)$. The findings of this investigation showed that ozonized oil or calcium hydroxide in CMCP can succeed in treating root canal infections by E. faecalis. However, the fact that some cases failed even in the group of twovisit treatment indicates that the search for new strategies to treat infected root canals should not stop.

Few studies have used clearly defined criteria to evaluate the outcomes of the endodontic treatment performed in one or multiple visits. In a well-controlled clinical study, Sjögren et al. (3) reported an overall success rate of $83 \%$ for root canals treated in a single visit. These findings can be directly compared to others from the same research group (4). Success was reported for $94 \%$ of the infected root canals associated with periradicular lesions treated in multiple visits when the root canals were filled within $2 \mathrm{~mm}$ short of the root apex (the same conditions as the one-visit study). Thus, a difference of $11 \%$ could be detected between singleand multi-visit treatments.

In another clinical study, Trope et al. (5) evaluated the radiographic healing of teeth with periradicular lesions treated in one visit or in two visits using calcium hydroxide as intracanal medication and found that the additional disinfecting action of calcium hydroxide resulted in a $10 \%$ increase in healing rates. Histological studies in animals $(16,20)$ also reported a higher success rate of the treatment when an intracanal medicament was left in the canal between appointments. The present study also using an animal model revealed a 30\% difference in the success rate between one- and twovisit treatments. From a clinical standpoint, this difference can be considered high and points to the need for the use of intracanal medicaments in the treatment of infected root canals.

In conclusion, the findings of the present study give support to the assertion that an interappointment antimicrobial dressing is necessary to predictably eliminate microorganisms from infected root canals and consequently to achieve a better outcome of the endodontic therapy. Moreover, the ozonized oil has the potential to be used as an intracanal medication.

\section{RESUMO}

O número de sessões necessárias para tratar um canal radicular infectado é um dos assuntos mais controversos da endodontia. $\mathrm{O}$ objetivo deste estudo foi analisar, em cães, a resposta dos tecidos perirradiculares ao tratamento endodôntico de canais infectados em uma ou duas consultas, usando diferentes medicamentos entre as sessões. Lesões perirradiculares foram induzidas pela inoculação de Enterococcus faecalis nos canais. Após a confirmação do desenvolvimento de uma lesão perirradicular, os canais foram tratados em uma ou duas sessões, usando óleo ozonizado ou hidróxido de cálcio associado ao paramonoclorofenol canforado (PMCC) como medicação intracanal. Após 6 meses, os animais foram sacrificados e os espécimes processados para análise histológica e histobacteriológica. Os canais tratados em sessão única apresentaram uma taxa de sucesso de $46 \%$ dos casos. Quando a medicação usada entre as sessões foi o hidróxido de cálcio associado com o PMCC, 74\% dos casos resultaram em sucesso. Nos casos em que o óleo ozonizado foi usado, uma taxa de sucesso de $77 \%$ foi observada. Esses achados demonstraram que o tratamento em duas sessões oferece uma taxa de sucesso mais alta quando comparado à terapia em uma sessão. Além 
disso, o óleo ozonizado mostrou potencial para ser usado como medicação intracanal.

\section{REFERENCES}

1. Siqueira JF Jr. Strategies to treat infected root canals. J Calif Dent Assoc 2001;29:825-837.

2. Bergenholtz G, Spangberg L. Controversies in endodontics. Crit Rev Oral Biol Med 2004;15:99-114.

3. Sjögren U, Figdor D, Persson S, Sundqvist G. Influence of infection at the time of root filling on the outcome of endodontic treatment of teeth with apical periodontitis. Int Endod J 1997;30:297-306.

4. Sjögren U, Hägglund B, Sundqvist G, Wing K. Factors affecting the long-term results of endodontic treatment. J Endod 1990;16:498-504.

5. Trope M, Delano EO, Orstavik D. Endodontic treatment of teeth with apical periodontitis: single vs. multivisit treatment. J Endod 1999;25:345-350.

6. Byström A, Sundqvist G. The antibacterial action of sodium hypochlorite and EDTA in 60 cases of endodontic therapy. Int Endod J 1985;18:35-40.

7. Siqueira JF Jr, Magalhães KM, Rôças IN. Bacterial reduction in infected root canals treated with $2.5 \% \mathrm{NaOCl}$ as an irrigant and calcium hydroxide/camphorated paramonochlorophenol paste as an intracanal dressing. J Endod 2007;33:667-672.

8. Siqueira JF Jr, Lopes HP. Mechanisms of antimicrobial activity of calcium hydroxide: a critical review. Int Endod J 1999;32:361-369.

9. Rilling S. The possibilities of medical ozone applications in light of the historical development of ozone therapy. Ozonachrichten 1983;2:27-39.
10. Washuttl J, Viebahn R. Ozoniziertes olivenö1 Fusammensetzungund desinfizierende wirksamkeit. Ozonachrichten 1982;1:25-29.

11. Elford WJ, van den Ende J. An investigation of ozone as an aerial disinfectant. J Hyg 1942;42:240-265.

12. Guinvarch P. Three years of ozone sterilization of water in Paris. Adv Chem Serol 1959;21:416.

13. Broadwater WT, Hoehn RC, King PH. Sensitivity of three selected bacterial species to ozone. Appl Microbiol 1973;26:391-393.

14. Siqueira JF Jr, Rôças IN, Cardoso CC, Macedo SB, Lopes HP. Antibacterial effects of a new medicament - the ozonized oil - compared to calcium hydroxide pastes (original article in Portuguese). Rev Bras Odont 2000;57:252-256.

15. Siqueira JF Jr, Rôças IN. Polymerase chain reaction-based analysis of microorganisms associated with failed endodontic treatment. Oral Surg 2004;97:85-94.

16. Katebzadeh N, Hupp J, Trope M. Histological periapical repair after obturation of infected root canals in dogs. J Endod 1999;25:364-368.

17. Zappi E. Organic Chemistry (original textbook in Spanish). Buenos Aires: El Ateneo; 1952.

18. Shapiro S. The inhibitory action of fatty acids on oral bacteria. Oral Microbiol Immunol 1996;5:350-355.

19. Sundqvist G, Figdor D, Persson S, Sjögren U. Microbiologic analysis of teeth with failed endodontic treatment and the outcome of conservative re-treatment. Oral Surg 1998;85:8693.

20. Tanomaru Filho M, Leonardo MR, da Silva LA. Effect of irrigating solution and calcium hydroxide root canal dressing on the repair of apical and periapical tissues of teeth with periapical lesion. J Endod 2002;28:295-299. 